\title{
Drivers and forecasting inflation for Agreement Agadir countries
}

\author{
Ahlem Dahem $^{1}$, Dhafer Saidane ${ }^{2}$, Fatma Siala Guermazi ${ }^{1}$ \\ ${ }^{1}$ Integration Laboratory of International Economic, FSEGT, University Tunis EL MANAR, Tunis, Tunisia \\ ${ }^{2}$ EQUIPPE-Université de Lille Nord de France and Skema Business School, Université Charles de Gaulle Lille 3, France \\ Email address: \\ ahlem.daham@gmail.com (A. Dahem), dhafer.saidane@skema.edu (D. Saidane), fatmasialag@gmail.com (F. S. Guermazi)
}

\section{To cite this article:}

Ahlem Dahem, Dhafer Saidane, Fatma Siala Guermazi. Drivers and Forecasting Inflation for Agreement Agadir Countries. Journal of World Economic Research.Special Issue: Issues and Challenges of the Financial and Economic Crisis throughout the World.

Vol. 3, No. 6-1, 2014, pp. 33-38.doi: 10.11648/j.jwer.s.2014030601.15

\begin{abstract}
The question of the determination of effective forecasting models, for macroeconomic variables, is still considered crucial for the monetary authorities. On the academic side, the interest aroused by this issue in international economics has been a subject of major debate at the center of the recent literature. This last demonstrate that predictions are crucial for the conduct of monetary policy. In order to find inflation divers and powerful models to explain clearly the dynamic of prices and inflation forecasting, this research gives special importance to inflation forecasting and represents an empirical comparison test of three models for predicting the inflation in the case of the countries of the Agadir Agreement of 2007 (Tunisia, Morocco, Egypt, Jordan) : the mark-up model, the monetary model and the Phillips curve through two econometric approaches: individual time series and panel data over the period 1990 - 2013. For comparison of prevision, we used the structural break test Bai and Perron (2003) and the RMSE criterion. We show that the mark-up model is the best suited for forecasting inflation and our results confirm our expectations.
\end{abstract}

Keywords: Monetary Policy, Inflation Drivers, Inflation Forecasting, Monetary Model, Mark-Up Model, Phillips Curve

\section{Introduction}

Maintaining price stability is the main objective of most central banks (CB). In this respect, the debate on the control of inflation by monetary authorities led to the inclusion of the concept of expected inflation by demonstrating that the predictions and expectations are crucial in the conduct of monetary policy.

On the one hand, they ensure their credibility by publishing permanently information on the forecasts produced by the $\mathrm{CB}$. On the other hand, it should be noted that with these forecasts, policymakers must take preventive action in cases of deviation from inflation in a significant gap Monetary authorities employ the necessary actions to eliminate the inflation gap; for example: change instruments of monetary policy before inflation starts to increase. Finally, the inflation forecasts are a major determinant for anchors expectations of economic agents. In this regard, the success of forecasting inflation depends on the ability of monetary authorities to anticipate future inflation. For this reason, CB must develop sophisticated econometric models to support their forecasting work by using advanced estimation methods, indicators and variables that contain most information about future inflation.

Academically, the interest aroused the question of forecasting inflation in international economics was a major debate in the center of the recent literature by distinguishing between the main drivers of Inflation. In general there are three drivers of inflation: monetary origin for inflation - cost push inflation - demand inflation. From this main drivers of inflation-cited above, we can talk about three types of inflation forecasting models integrating different variables. Several researches have focused on the ability of monetary aggregates to anticipate inflation rate (Altimari (2001), King (2002), Vizek and Broz (2007), Horvat and RozsypalKomarek (2011)). Some studies carried out by De Brouwer and Ericsson (1995), De Brouwer and Ellis (1998), have shown that the weak impact of monetary aggregate on domestic prices, the results show that others macroeconomic variables such as output, wages, foreign prices, exchange rates have important impact on domestic price and anticipate inflation which is equated with mark-up theory. In the same context, García and Restrepo (2001), Bardsen, Jansen and 
Nymoen (2003), Bowdler and Jansen (2004), Serrato (2006), Monfort and Peña (2008) suggest that the reaction under mark-up framework allow providing robust answers to show the important impact of domestic and foreign factors on inflation rate.Moreover, some research have analyzed the relationship between inflation and factor demand (gross domestic product), they have attempted to test the reliability of the Phillips curve in terms of prediction of inflation (Engert and Hendry (1998) Stock and Watson (1999), Matheson (2006), Norman and Richards (2010)). Indeed, few studies have compared the quality of prediction of the Phillips curve to different models that predict inflation such as Markup model and models based on monetary aggregates (Bailliu, Garcés, Kruger and Messmacher (2003), Heath, and Tim Roberts (2004), Domac (2004), Boschi and Girardi (2007),Alexová (2012), Liew (2012)). However, the theoretical and empirical analysis are still mixed for this issue and work addressing drivers and forecasting inflation are very scarce for Agadir Agreement countries in general and Tunisian case in particular.

Our motivation is to study the context of the Agadir countries (Tunisia, Morocco, Egypt, Jordan) that was not properly applied as the sample of countries. Thus, our goal in this work is to establish a comparative empirical approach that allows providing robust answers to analyze drivers and forecasting inflation in some emerging market that have similarities in monetary policy and some common points. We try to empirically compare three models of inflation forecasting: the mark-up model, the monetary model and the Phillips curve. We follow two empirical methodologies: time series estimations and a panel approach to examine these issues. Most studies that have addressed this issue have been only based on individual analyzed using time series analysis. A panel analysis provides some advantages, it help us to formulate dynamic models, a better accuracy and identification of estimated coefficients and cointegration tests are stronger on temporal panel data than on individual time series, especially in a small sample. We structure the paper such that: section two present the institutional framework of the agreement of Agadir. Section threeis an empirical study; it gives the estimations results and the discussion. Section four is devoted to the prevision comparison. Finally, we give the conclusion.

\section{Agadir Agreement}

The Agadir Agreement aims to create a free trade area between the four countries classified as economies emerging (IMF, 2008): Morocco, Tunisia, Egypt and Jordan. This is a prelude to the future Euro-Mediterranean free trade area. This initiative was supported by the European Commission, both politically and financially.

The Agadir Agreement was launched in Morocco in May 2001, when Jordan, Tunisia, Egypt and Morocco have declared their intention to establish a free trade area between them, with the support of the European Union. It was signed inRabat, Kingdom of Morocco on February 25, 2004. It entered into force on July 6, 2006 after the completion of the ratification procedures in the four signatory countries. The effective implementation of the Agadir agreement began March 27, 2007 when the customs crossing points of the signatory countries were notified of the entry into force of the agreement. Certainly, Egypt, Jordan, Morocco and Tunisia are competing countries in terms of size, population, growth and openness. But the structure of the economy is similar, including Egypt, Morocco and Tunisia. Only Jordan stands out the group with a strong dominance of services and a paltry contribution of agriculture to GDP. Unlike other MENA countries, their oilresources are limited or nonexistent. Second, financial transfers by migrants play a major role in reducing poverty, especially in Egypt, Jordan and Morocco (Berument and Ceylon (2004)). On the monetary side, a similarity appears between the countries of the Agadir Group: despite the divergence of their exchange rate regimes, they discussed the transition to inflation targeting policy since 2006 (IMF (2006)).

\section{Empirical Analysis}

\subsection{Econometric Methodology}

Our problem is the following: What are the variables that can provide better information about future inflation? To provide an empirically answer, we chose to test the ability of three models: Mark up model, the monetary model and the Phillips curve in anticipating inflation. Then, we identify the variables that have the most information on inflation for Tunisia in a first step and thus for the Agadir countries in general. Our research will focus on estimating these three models following three aspects of inflation. The choice was based on the motivation that these models have been widely used in the literature and they include different variables that can represent the majority of the causes of inflation, which enables us to respond to our problem. The models are those benchmarks of the work of Bailliu, Garcés Kruger Messmacher (2003), Domac (2004) and Alexová (2012).

\subsubsection{Monetary Aspect for Inflation}

$$
\Delta \mathrm{p}_{\mathrm{t}}=\alpha_{0}+\sum_{i=1}^{k}\left(\alpha_{\mathrm{i}} \Delta \mathrm{p}_{\mathrm{t}-\mathrm{i}}\right)+\sum_{i=1}^{k}\left(\beta_{\mathrm{i}} \text { moneygap }_{\mathrm{t}-\mathrm{i}}\right)+\varepsilon_{\mathrm{t}}
$$

With $\mathrm{p}_{\mathrm{t}}$ : the level of prices measured by the index of consumer prices (CPI). Money gap t. $_{1}$ : it is the difference between the money supply and the trend of long-term demand for money. For monetary variable we take the monetary aggregate $\mathrm{M} 3$ as a measure of stock currency. To

\footnotetext{
1. Money gap $=\mathrm{m}_{\mathrm{t}}-\mathrm{m}_{\mathrm{t}}{ }^{*}$, as it is performed $\mathrm{mt}$ is money supply (real) and $\mathrm{m}_{\mathrm{t}}^{*}$ is the demand for long-term change. Among the most used methods to estimate the trend of long-term demand for money is the Hodrick-Prescott (HP) filter allows excluding the cyclical component of the evolution of the latter. Indeed, the supply of currency $\mathrm{m}_{\mathrm{t}}$ is the sum of two components: a cyclical $\mathrm{m}_{\mathrm{t}}^{\mathrm{c}}$ and the other on the normal growth $\mathrm{m}_{\mathrm{t}}^{\mathrm{g}}\left(\mathrm{m}_{\mathrm{t}}=\mathrm{m}_{\mathrm{t}}^{\mathrm{g}}+\mathrm{m}_{\mathrm{t}}^{\mathrm{c}}\right)$. The application of the HP filter for a series $\mathrm{mt}$ is to determine normal $\mathrm{mtg}$ component amounts to the following expression $\left.\mathrm{m}_{\mathrm{t}=1: \mathrm{T}}^{*}=\arg \min \mathbb{I}_{\mathrm{t}-1}^{T}\left[\mathrm{ggap}^{2}\right)+\lambda\left(\Delta^{2} \mathrm{~m}_{\mathrm{t}}^{*}\right)^{2}\right]$.With: $\mathrm{m}_{\mathrm{t}}^{*}=$ long-term demand for money, as $\mathrm{m}_{\mathrm{t}}{ }^{*}=\mathrm{m}_{\mathrm{t}}^{\mathrm{g}}$, Gap $=$ money gap $=\mathrm{m}_{\mathrm{t}}-\mathrm{m}_{\mathrm{t}}{ }^{*}$. Where $\lambda$ is a penalty factor in the variability of normal growth component of the production; it is set to 1600 by Hodrick and Prescott for quarterly data.
} 
determine the trend in the demand for money in the long run we have had recourse to the Hodrick-Prescott filter (HP), which allows excluding the cyclical component of the evolution of the relevant variable.

$$
\Delta \mathrm{p}_{\mathrm{t}}=\alpha_{0}+\sum_{\tilde{t}=1}^{k}\left(\alpha_{\mathrm{pi}} \Delta \mathrm{p}_{\mathrm{t}-\mathrm{i}}\right)+\sum_{i=1}^{k}\left(\alpha_{\mathrm{wi}} \Delta \mathrm{w}_{\mathrm{t}-\mathrm{i}}\right)+\sum_{i=1}^{k}\left(\alpha_{\mathrm{ei}} \Delta \mathrm{E}_{\mathrm{t}-\mathrm{i}}\right)+\sum_{i=1}^{k}\left(\alpha_{\mathrm{pi}} \Delta_{\mathrm{p}_{\mathrm{t}-\mathrm{i}}}^{*}\right)+\delta \mathrm{ecm}_{\mathrm{t}-1}+\varepsilon_{\mathrm{t}}
$$

With pt: the price level, measured by the index of consumer prices (CPI). wt: cost of labor, wage. Et: the bilateral nominal exchange rate: domestic currency/ EUR2.

$\mathrm{Pt} *$ : the foreign price: the index of consumer prices (CPI) in the Euro zone.

Ecmt: error correction model3.

\subsubsection{Inflation Driven by Demand}

$$
\Pi_{\mathrm{t}}=\alpha+\beta_{1}(\mathrm{~L}) \Pi_{\mathrm{t}}+\beta_{2}(\mathrm{~L}) \text { outputgap }_{\mathrm{t}}+\beta_{2}(\mathrm{~L}) \Delta \mathrm{S}_{\mathrm{t}}+\varepsilon_{\mathrm{t}}
$$

With $\Pi \mathrm{t}$ : the rate of inflation, as the first two models is measured by the index of consumer prices (CPI).St: the bilateral nominal exchange rate, in this case: EUR / domestic currency. Output gap $\mathrm{p}_{\mathrm{t}}$ : is the gap between actual production and potential long-term production. As is already shown before for calculating money gap, we use the HP filter to calculate the potential output.

\subsection{Data}

Our empirical methodology is based on two methods of estimation:

* Estimation of time series: the sample is Tunisia, over the period 1990: Q1- 2012:Q4.

* Estimation on panel data: our sample contains four member countries of the Agadir Agreement, based on annual data over the period $1990-2013$.

This passage was constrained by the availability of data. Indeed, the choice of temporality: the annual frequency, we was dictated by the availability of data for these countries. We were constrained by the availability of data for the choice of the study period, especially wages and GDP. The sources of these data are the International Financial Statistics of the IMF and the World Bank website.

\subsection{Estimation Results4}

\subsubsection{Monetary Aspect for Inflation}

Table 1. Estimation of monetary model

\begin{tabular}{lll}
\hline Variables & Tunisia (OLS estimation) & $\begin{array}{l}\text { Agadir countries } \\
\text { estimation) }\end{array}$ \\
\hline cste & $0.002810 *(0.0001)$ & - \\
\hline
\end{tabular}

2The NER is the bilateral exchange rate against the euro. For example: the Tunisian trade is done by approximately $70 \%$ with the euro zone. Thus an increase in NER reflects a bilateral nominal depreciation of the Tunisian dinar against the euro.

3 ECM represents long term relationship of cointegration, $\delta$ coefficient of adjustment and restoring force to the LT equilibrium

4 Estimation of Blundell and Bond (1998) or GMM system that is used. All estimates are made by the author on Eviews8and Stata12. Note: the *, ** and *** represent significance levels, respectively, $1 \%, 5 \%$ and $10 \%$.

\subsubsection{Cost push Inflation}

\begin{tabular}{lllll}
\hline dlcpi(-1) & $0.456491^{*}$ & $(0.0002)$ & $-0.6034291^{*}(0.000)$ \\
dlcpi(-2) & -0.178767 & $(0.1304)$ & - & \\
$\operatorname{lm} 3 \operatorname{gap}(-1)$ & -0.013202 & $(0.6436)$ & -1.13836 & $(0.905)$ \\
$\operatorname{lm} 3 \operatorname{gap}(-2)$ & $-0.087120^{*}$ & $\left(0.0027^{*}\right)$ & - & \\
$\operatorname{lm} 3 \operatorname{gap}(-3)$ & $0.095417^{*}$ & $\left(0.0006^{*}\right)$ & - & \\
\hline
\end{tabular}

Source: Author's estimations.

\subsubsection{Cost Push Inflation}

The mark-up model is an error correction model (ECM) of the autoregressive distributed lag ARDL approach to model the short-term dynamics by integrating the long-term effect.

*The long-term relationship

Table 2. Estimation long-term mark-up model

\begin{tabular}{lllll}
\hline Variables & Tunisia (OLS estimation) & \multicolumn{2}{l}{$\begin{array}{l}\text { Agadir countries } \\
\text { (FMOLS estimation) }\end{array}$} \\
\hline cste & $2.310277^{*}(0.000)$ & - & \\
$\gamma_{\mathrm{w}}$ & $0.265145^{*} \quad(0.000)$ & $0.312678^{*}$ & $(0.000)$ \\
$\Gamma_{\mathrm{e}}$ & $-0.019089^{* *}$ & $(0.0332)$ & $-0.250523^{* *}$ & $(0.0112)$ \\
$\Gamma_{\mathrm{p}}$ & $0.296445^{*}$ & $(0.0000)$ & $0.540003^{* *}$ & $(0.0464)$ \\
\hline
\end{tabular}

Source: Author's estimations.

*Short-term dynamics

Table 3. Estimation short term mark-up model (ECM)

\begin{tabular}{lll}
\hline Variables & Tunisia (OLS estimation) & $\begin{array}{l}\text { Agadir countries (OLS } \\
\text { estimation) }\end{array}$ \\
\hline cste & $0.009068^{*}(0.002783)$ & - \\
EC $(-1)$ & $-0.041104^{*}(0.0000)$ & $-0.085010^{* *}(0.0485)$ \\
dlcpi(-1) & $0.329935^{*}(0.0013)$ & $0.328195^{*}(0.0041)$ \\
dlcpi(-2) & $-0.230214^{* *(0.0244)}$ & $0.446978^{*}(0.0001)$ \\
dlwage(-1) & $0.004790(0.8759)$ & $-0.055235^{*}(0.0008)$ \\
dlwage(-2) & $-0.029449(0.3339)$ & $-0.000823(0.9677)$ \\
dlexchr(-1) & $0.020814(0.2541)$ & $-0.065478^{*} *(0.0696)$ \\
dlexchr(-2) & $-0.041376^{* *}(0.0240)$ & $0.046665^{* * *}(0.0784)$ \\
dlp*(-1) & $-0.122310(0.3087)$ & $0.428041(0.1574)$ \\
dlp*(-2) & $0.304279 * *(0.0137)$ & $0.082685(0.7713)$ \\
\hline
\end{tabular}

Source: Author's estimations.

\subsubsection{Inflation Driven by Demand}

\begin{tabular}{|c|c|c|}
\hline Variables & Tunisia (OLS estimation) & $\begin{array}{l}\text { Agadir countries } \\
\text { (GMM estimation) }\end{array}$ \\
\hline cste & $0.003085 *(0.0000)$ & - \\
\hline dlcpi(-1) & $0.378994 *(0.0005)$ & $-1.54 \mathrm{e}-14 *(0.000)$ \\
\hline dlcpi(-2) & $-0.126329 \quad(0.2374)$ & - \\
\hline $\operatorname{dlS}(-1)$ & $-0.014943(0.4496)$ & $1 * \quad(0.000)$ \\
\hline $\operatorname{dlS}(-2)$ & $0.049840 *(0.0132)$ & - \\
\hline 1GDPgap(-1) & $-0.005769 \quad(0.9351)$ & $5.42 \mathrm{e}-15 \quad(0.182)$ \\
\hline 1GDPgap(-2) & $-0.034718 \quad(0.6201)$ & - \\
\hline
\end{tabular}

Table 4. Estimation Phillips curve

Source: Author's estimations.

First, there is higher significant weight delayed inflation in 
the three models, in the case of Tunisia in particular and the Agadir countries in general. This intrinsic inertia of past inflation is linked to inflation persistence sustained throughout the past periods for these countries (Tunisia, Morocco, Egypt, Jordan). Secondly, we see a relatively large impact of domestic costs on long-term prices (wages) as foreign factors (foreign prices and exchange rates).For Tunisia: a $100 \%$ increase in wages and foreign prices in national currency increased long-term price of $26 \%$ and $27 \%$ respectively. For the countries of Agadir: a 100\% increase in wages and foreign prices in national currency increased the long-term price of $31 \%$ and $30 \%$ respectively. In the short term, the EC represents the coefficient of adjustment and the restoring force towards equilibrium, is negatively significant and it's low to Tunisia in particular and the country in general Agadir, around $4 \%$ and $8.5 \%$ respectively. We also note a low significance of the coefficients of the monetary model and the Phillips curve, both monetary variables and the output gap is not significant. Our results can be confirmed, in fact, the effects of the exchange rate transmission (passthrough) in the short term and long term related to appreciation or depreciation of the exchange rate on consumer prices are remarkable in the case of emerging countries in general and in the case of these particular countries.

\subsubsection{Discussion: Tunisian Context}

Since the 2009 financial crisis and the turmoil after the revolutions experienced in most of these Agadir Agreement countries, the conduct of monetary policy has not been easy work, as it faced several challenges at a time; price stability, the ultimate priority objective of any central bank, was not at all assured, with runaway inflation. As a first result we note that money creation does not cause an increase in inflation. This in fact was confirmed by the economic environment in these countries and especially Tunisia. Indeed, in Tunisia: The M3 recorded a downward trend that began in 2009. The growth rate of M3 which reached $13 \%$ in $2009,12.1 \%$ in 2010 to $9.1 \%$ in 2011 and $8.4 \%$ in 2012 . The review of the economy's liquidity, as measured by the ratio M3 / GDP shows that the money supply stood at levels consistent with the evolution of the activity, reflecting the absence of inflationary pressures of monetary origin. In parallel, the continued evolution of free prices at a steady pace $(7.2 \%$ on in 2013 average against 7\% in 2012), coupled with the rising price of administered products (3.6\% in 2013 against $2.4 \%$ in 2012) contributed to the exacerbation of inflationary pressures. From 2011 until 2013, the evolution of inflation in Tunisia is attributable to the increase in wages (both in agriculture as non-agricultural), the continued depreciation of the dinar vis-à-vis major currencies in particular the Euro and the dollar: the pass-through of the exchange rate $(7 \%$ and $3.9 \%$ in 2013 against $2.5 \%$ and $9.9 \%$ in 2012) and distribution channels disturbances, both, adverse weather conditions that affected the agricultural season that parallel trade operations with neighboring countries. To this is added an unprecedented increase in compensation costs that pushed the government to make some adjustments in administered prices affecting the price changes. In addition, despite the uncertainty surrounding the measures of the output gap, it is unlikely that inflationary pressures have an influence on production capacity. In this dynamic inflationary environment, the monetary authorities has tried to lead a tighter monetary policy for stabilize the inflation rate (Since 2011)5.

\section{Prevision Comparison}

Once the estimates are made, it remains to choose the best model to predict inflation in these countries. Indeed, any forecast results values releasing deviations from the achievements. The predictive accuracy can be measured in several ways. In general, the choice of a prediction comparison criterion which may be decisive in a comparison between these models depends mainly on its use, quantitative evaluation of the precision and also its reliability prediction. However, we retain two criteria: MAD and RMSE for their high sensitivity, their common uses, their interpretive faculties and their implementation easier. So these two criteria are used to compare the forecast performance.

- The Mean Absolute Deviation: MAD(e) $=\frac{1}{n} e_{i} \mid-$ Moy(e) $\mid$

- The Root Mean Square Error: $\operatorname{RMSE}(e)=\sqrt{\frac{1}{n} e_{i} 2}$

To achieve our goal: the comparison between the predictions, we will make an out-of-sample, estimation; divide the period into two and estimate models for the first time, then consider the observations as forecasts for the second period. In order to ensure the appropriate date of the change, a structural change test Bai and Perron (1998, 2003) is made to have the dates of breaks (we use the methodology of Bai-Perron for identification of structural breaks in the time series). Structural changes in dates of the CPI released are considered dates forecast. 6

Table 5. Forecasting performance comparison according to the RMSE criterion

\begin{tabular}{lll}
\hline Models & Tunisia & Agadir countries \\
\hline Mark-up & 0.002233 & 3,31093464629514 \\
Monetary Model & 0.002243 & 4,92569224033333 \\
Phillips Curve & 0.002395 & 5,4415472848026 \\
\hline
\end{tabular}

The results in the table, the model that minimizes the RMSE criterion is chosen as a good model for prediction. Thus, the best model for Tunisia and Agadir Agreement countries is the Mark up. Indeed, this model requires variables as domestic and foreign production costs, this is confirmed by economic reality since the weight of wages is important in explaining and price dynamics of exchange rate movements affect both prices domestic (pass-through). The result confirms what we found before in the previous section of the estimated models. Thus in the case of these countries,

5 Annual Report of the CBT (2013)

6Tunisia: the estimation period: 1990: Q1-2000: Q4 and the forecast period 2001: Q3-2013: Q3. Agadir countries: the estimation period: 1990-2005 and the forecast period: 2006-201. 
wages and exchange rate variables have a significant effect on the price change.

\section{Conclusion}

Face to the controversies concerning the relevance of expected inflation models, we thought that is important to study the role and the ability of Central Bank to anticipate inflation from three models mentioned above and compare them. Indeed, under this empirical analysis we have tried to find the convenient model and variables that can better anticipate inflation. We found that domestic and foreign factors of production such as: wages, changes in the exchange rate and foreign prices have a major impact on the change in inflation for Agadir countries in general and Tunisia in particular. As a result, the Mark up model appears the best model to anticipate inflation. Our comparison results were concluded through the comparison criteria based on the forecast error (the root mean square, RMSE). Therefore, we can say that our results support the economic reality for these countries.

At the end of this research, which is a preparatory to a future research we can extend our work basing on more recent econometric methods to expected inflation; like Bayesian method which appear necessary for a further deepening related to this topic (Lajmi M. and El Khadraoui S (2014)).

However, the positive aspects should not obscure the efforts still required, but also the obstacles underlying that have held back some reforms. In this context, the vulnerability of the monetary economy of the Agadir countries after the financial and economic crisis has demonstrated the political, while reforms suffer from structural barriers and a fluctuation of exchange rate.

\section{Acknowledgement}

We would like to particularly thank Dr. Olfa Manai Daboussi for her suggestions.

\section{References}

[1] Aron, J\& J. Muellbauer (2012), «Improving forecasting in an emerging economy, South Africa: Changing trends, long run restrictions and disaggregation», International Journal of Forecasting, Volume 28, Issue 2, April-June 2012, Pages 456476.

[2] Alexova M. (2012), « Inflation drivers in new EU members » Working paper NBS (2012), National Bank of Slovakia.

[3] Altimari S.N., (2001), « Does Money lead Inflation in the Euro Area? », European Central Bank working paper, No. 63.

[4] Annual report of CBT(2013), http://www.bct.gov.tn/bct/siteprod/english/publications/rappor t.jsp

[5] Bailliu J., Garcés D., Kruger M. \& Messmacher M., (2003), « Explaining and Forecasting Inflation in Emerging Markets:
The Case of Mexico», Bank of Canada Working Paper, No.17.

[6] Bardsen G., Jansen E. \& Nymoen R., (2003), « Econometric inflation targeting »,Econometrics Journal, Vol6, pp. 429-460.

[7] Berument, H. \& Ceylan, N.B., (2004), «The Impact of Oil Price Shocks on the Economic Growth of the Selected MENA Countries». Paper presented at the 12th Annual Conference of Economic Research Forum (ERF), Cairo, Egypt, December 2005.

[8] Boschi, M. \& Girardi, A. (2006), « Does One Monetary Policy Fit All? The Determinants Of Inflation in EMU Countries », European University Institute Working Paper 2002/16.

[9] Boschi, M. \& Girardi, A. (2007), « Euro Area inflation: longrun determinants and short-run dynamics », Applied Financial Economics, Taylor and Francis Journals, vol. 17(1), pages 9-24.

[10] Bowdler C. \& Jansen E., (2004), « A Markup Model of Inflation forthe Euro Area ", European Central Bank working paper series, No.306.

[11] Charfi F. \& Guermazi F. (2012), « Transmission of Nominal Exchange Rate Variation to Domestic Prices and Monetary Policy in Tunisia ", International Review of Business Research Papers Vol. 8.No.5. July 2012. Pp. 41 - 54

[12] ChianFatt, Liew Freddy (2012), « Forecasting Inflation in Asian Economies », MPRA Paper 36781, 2012, University Library of Munich, Germany.

[13] De Brouwer G. \& Ericsson N., (1995), « Modeling inflation in Australia», Reserve Bank of Australia, working paper, No.9510.

[14] De Brouwer G. \& Ellis L., (1998), « Forward-Looking Behaviour and Credibility: Some Evidence and Implications For Policy », Reserve Bank of Australia, Research Discussion Paper, No.9803.

[15] Domaç I., (2004), « Explaining and Forecasting Inflation in Turkey ", World Bank Policy Research Working Paper, No.3287, Public Disclosure Authorized.

[16] Engert W.\& Hendry S., (1998), « Forecasting Inflation with the M1-VECM », Bank of Canada Working Paper, No. 98-6, Part 2.

[17] Ericsson N.R., (2009), « Constructive Data Mining: Modeling Australian Inflation ", working paper (http://www.economics.smu.edu.sg/events/Paper/NeilEricsson Australian.pdf)

[18] García C. \& Restrepo J., (2001), " Price inflation and exchange rate pass-through in Chile ", Central Bank of ChileWorking Papers, No.128.

[19] Goaied, M \& Sassi, S. (2012), « Module $\mathrm{n}^{\circ} 1$ : économétrie des données de panel sous STATA », MAI 2012, LEFA, IHECTUNIS.

[20] Hansen, H. and Johansen, S. (1999), " Some tests for parameter constancy in cointegrated VAR Models », Econometrics Journal, vol.2, pages 306-33.

[21] Heath A., Roberts I. \& Bulman T., (2004), " Inflation in Australia: Measurement and Modeling », Reserve Bank of Australia, «The future of inflation targeting», pp.140-219.

[22] Horváth, R., Komárek, L., \& Rozsypal, F. (2011), «Does Money Help Predict Inflation? An Empirical Assesment for Central Europe», Economic Systems, 35(4), 523-536. 
[23] IMF, 2006 (a), «Tunisie - Conclusions préliminaires de la mission de consultation au titre de l'article iv pour l'année 2005». FMI, Washington, D.C.

[24] IMF, 2006 (b), «Inflation Targeting and the IMF».FMI, Washington, D.C.

[25] IMF, 2006 (c), «Tunisia: 2006 Article IV Consultation-Staff Report, Staff Statement, Public Information Notice on the Executive Board Discussion, and Statement by the Executive Director for Tunisia». IMF Country Report No.06/207.IMF, Washington, D.C.

[26] IMF, 2006 (d), «De Facto Classification of Exchange Rate Regimes and Monetary Policy Framework». IMF, Washington, D.C.

[27] IMF, 2006 (e), «Tunisia: Financial System Stability Assessment Update ». IMF Country Report no.06/448. IMF, Washington, D.C.

[28] IMF, 2006 (f), «Maroc - Conclusions préliminaires de la mission de consultation au titre de l'article iv des statuts du Fonds Monétaire International». IMF, Washington, D.C.

[29] IMF, 2006 (g), «Arab Republic of Egypt: 2006 Article IV Consultation-Staff Report, Staff Statement; Public Information Notice on the Executive Board Discussion, and Statement by the Executive Director for the Arab Republic of Egypt». IMF Country Report No.06/253.IMF, Washington, D.C.

[30] King M., (2002), « No money, no inflation - the role of money in the economy Bank of England ", Bank of England Quarterly Bulletin, Vol. 42, No.2, pp. 162-177.

[31] Lajmi M. \& El Khadraoui S. (2014), «Medium-Term
Forecasting Model for Tunisia »,CBT July 2014, http://www.bct.gov.tn/bct/siteprod/documents/EBCT_2014072 4.pdf

[32] Manai Daboussi O. (2014), «Economic performance and inflation targeting in developing economies», Journal of World Economic Research. Vol. 3, No. 1, 2014, pp. 1-7.

[33] Matheson, T., (2006), « Phillips curve forecasting in a small open economy ", Working Paper Series of Reserve Bank of New Zealand, No.01.

[34] Monfort \& Peña (2008), «Inflation Determinants in Paraguay: Cost Push versus Demand Pull Factors », International Monetary Fund WP/08/270 IMF.

[35] Norman \& Richards (2010), « Modelling Inflation in Australia »RBA Research Discussion Papers rdp2010-03, Reserve Bank of Australia.

[36] Serrato J. C. S., (2006), «Forecasting Mexico's Inflation: the Effects of an Inflation Targeting Regime ", Forecasting Mexican Inflation, pp.123.(http://works.bepress.com/jc_suarez/1)

[37] Stock J. \& Watson M. W., (1999), « Forecasting Inflation», NBER working paper series, No. W7023.

[38] Öðünç, F K. Akdoðan, S. Baper, M. G. Chadwick, D. Ertuð, T. Hülagü, S. Kösem, M. U. Özmen, N. Tekatl (2013), « Shortterm inflation forecasting models for Turkey and a forecast combination analysis ", Economic Modelling, Volume 33, July 2013, Pages 312-325

[39] Vizek M. \& Broz T., (2007), « Modelling Inflation in Croatia » EIZ Working Papers, No.0703. 